\title{
Численно-аналитическое моделирование металлического зонда с заостренным концом в ближнепольной микроскопии
}

\section{Numerical-analytical modeling of the metal probe with pointed tip in near-field microscopy}

\section{Н. В. Селина}

Кубанский государственный

технологический университет, Россия

\section{N. V. Selina}

Kuban State Technological

University, Russia

Поступила в редакцию 09.07.2019, принята к печати 19.07.2019

\section{Абстракт}

Предложен аналитический метод проектирования металлического зонда с заостренным концом, используемого в подсветке ближнепольной микроскопии, сопровождаемый численным анализом. Показано, что расчет параметров зонда должен включать в себя моделирование кусочно-однородных сред сферической и цилиндрической симметрии. Резонансные свойства металлодиэлектрической структуры подсветки определяются условиями плазмонного резонанса одномерных и локализованных на острие зонда плазмонов.

\section{Abstract}

An analytical method for designing a metal probe with a pointed end used in near-field microscopy illumination, accompanied by numerical analysis, has been proposed. It is shown that the calculation of the probe parameters should include the modeling of piecewise homogeneous media of spherical and cylindrical symmetry. The resonance properties of the metal-dielectric structure of the illumination are determined by the conditions of the plasmon resonance of one-dimensional and localized plasmons on the tip of the probe.

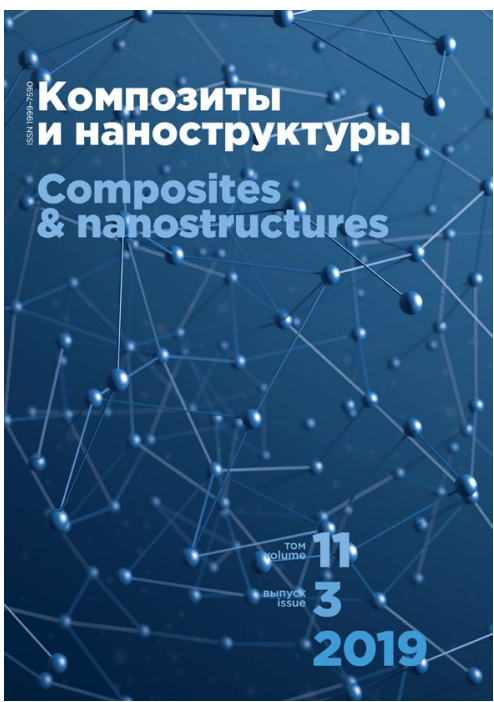

